\title{
TEACHER COMPETENCIES AND THEIR RELATIONSHIP WITH THE DEVELOPMENT OF INTERACTIVE MEDIA
}

\author{
Hidayat Herman \\ Program Magister Fakultas Bahasa dan Seni, Universitas Negeri Padang \\ Hidayatherman1997@gmail.com
}

Talking about teachers means talking about the front line in the progress of a nation (Leonard, 2016). How not, this noble profession is the root of the progress of civilization. The progress of a country depends on the level of education of that country. History records that when Japan lost in World War II, the first thing they did was collect how many teachers were still alive. This makes Japan now a country superpower. Japan's success is inseparable from how the country continues to improve the competence of their teachers.

Teacher competence can be interpreted as an ability or skill that must be possessed by a teacher. Mariyana (2016) asserts that competence is a set of knowledge, skills and behaviors that must be possessed, internalized, and mastered by teachers or lecturers in carrying out professional duties. Agusrida, et al. (2020) also explained that the competence that a teacher must have is to be able to develop professionalism on an ongoing basis by taking reflective actions, and using ICT to communicate and develop themselves.

The article written by Mulyadi, et al. (2020) states that in the 21 st century teachers as educators must be able to create innovations in the learning process to improve the learning achievement of their students. One form of innovation is to create effective and technology-based learning resources. Technology-based learning can bring education in a better and modern direction (Syahrul et al., 2021). Based on this, teachers are expected to be able to utilize technology in the learning process.

Technology in the learning process is one of the means to develop interesting learning models for students, so that students are motivated to learn independently. One form of technology that can be used is interactive media. Novelty, et al. (2018); Syarul, et al. (2019); and Atmazaki, et al (2021) explain that the media can provide direct experience to students. The media in question uses hardware, such as computers, televisions, projectors, LCDs, and software such as Microsoft PowerPoint, media macro flash, visual basic, audio visual, and others that are used on hardware.

Many reform efforts can be made by utilizing technology as a learning tool. The use of this technology is intended to improve the quality of student education (Mulyadi et al. 2019). But the problem now is, are all teachers ready for this rapid technological development? Based on research conducted by Leonard (2016) on 
approximately 60 teachers in DKI Jakarta, the results show that almost $75 \%$ of teachers do not prepare the learning process well. Teachers tend to prepare learning by prioritizing the material to be taught, not on the learning objectives. This shows that not to mention using the media, teachers are still at a disappointing level when preparing lessons well.

There are several things that can be done to overcome things like this, such as the solution offered by Agusrida et al., (2020). In the article written by Agusrida, there are three things that can improve teacher competence, namely effective training, scientific publication training, and online training. These three things are expected to improve teacher competence in making innovations in each lesson. Thus the professional competence of teachers must continue to be improved evenly so that the use of ICT in learning is no longer a rare thing to find for the progress of this nation and country. 